$\begin{array}{lccc}\text { POLISH JOURNAL } & \text { OF } & \text { SOIL } & \text { SCIENCE } \\ \text { VOL. XLIX/2 } & 2016 & \text { PL ISSN 0079-2985 }\end{array}$

DOI: $10.17951 / \mathrm{pjss} / 2016.49 .2 .149$

\title{
JOANNA LEMANOWICZ*, AGATA BARTKOWIAK** \\ CHANGES IN THE ACTIVITY OF PHOSPHATASE AND THE CONTENT OF PHOSPHORUS IN SALT-AFFECTED SOILS GRASSLAND HABITAT NATURA 2000
}

Received: 2017.03.06

Accepted: 2017.04.18

\begin{abstract}
The subject of this study was the humus horizons in the salt-affected soils of Natura 2000 (Ciechocinek, Poland). In the adequately prepared soil, there were determined: $\mathrm{pH}$ in $\mathrm{CaCl}_{2}$, total organic carbon (TOC), exchangeable cations $\left(\mathrm{Ca}^{2+}, \mathrm{Mg}^{2+}, \mathrm{Na}^{+}, \mathrm{K}^{+}\right)$, salinity $\left(\mathrm{EC}_{1: 5}\right)$, the content of total (TP) and available phosphorus (AP), the activity of alkaline (AlP) and acid (AcP) phosphatases. TOC affected the degree of saturation of the sorption complex with basic cations, as confirmed by correlation analysis. In the analysed soil samples a series of quantitative cations of basic character is as follows: $\mathrm{Ca}^{2+}>\mathrm{Na}^{+}>\mathrm{K}^{+}>\mathrm{Mg}^{2+}$. Increased salinity has modified the qualitative and quantitative composition of the soil solution. Correlation analysis confirmed the significant relationship between the conduction of the electrolytic soil and the content of sodium and potassium cations. The highest value of $\mathrm{EC}_{1: 5}$ was found in the soil sampled near the ditch (sites 12, 13, 16). According to PN-R-04023 (1996), this soil classifies as class V with a very low content of $\mathrm{P}$ available but the availability factor for phosphorus value ranged from 2.773 to $5.252 \%$ indicating that soil $\mathrm{P}$ was sufficient for plant growth in this habitat. Significant positive correlations were found between salinity, alkaline phosphatase and exchangeable $\mathrm{K}^{+}, \mathrm{Na}^{+}$. Significant negative correlations were found between $\mathrm{EC}_{1.5}$ with $\mathrm{P}$ available and the availability factor for this nutrient (AF). The positive significant correlations among soil alkaline phosphatase and some physicochemical properties suggested that salinization had effects on these variables. Alkaline phosphatase may be used as indicators of soil quality in salinized grassland habitat Natura 2000.
\end{abstract}

Keywords: base cations, electrical conductivity, phosphatase, phosphorus, salt-affected soils

* Sub-Department of Biochemistry, Faculty of Agriculture and Biotechnology, University of Science and Technology, 85-029 Bydgoszcz, 6 Bernardyńska St., Poland

** Department of Soil Science and Soil Protection, Faculty of Agriculture and Biotechnology, University of Science and Technology, 85-029 Bydgoszcz, 6 Bernardyńska St., Poland, e-mail: j109@interia.pl 


\section{INTRODUCTION}

The main measure implemented to protect the environment on a European Union (EU) scale was the establishment of the European Ecological Network Natura 2000 in order to preserve valuable natural or semi-natural areas (Bartula et al. 2011; Grodzinska-Jurczak and Cent 2011). Natura 2000 network already covers about $18 \%$ of EU territory. Concerted effort to preserve the natural heritage of Europe on the basis of a uniform law aims at optimizing costs and increasing beneficial results for the environment (Wamelink et al. 2013). The EU rules, which form the basis for the creation of the Natura 2000 network, were incorporated into the Polish legislation system with the publication of the Nature Conservation Act of 16 April 2004. Therefore, under the EU Habitats Directive (Council Directive 92/43EWG) providing proper status of Natura 2000 habitats is one of the most important tasks of nature conservation in Poland.

The salinity of soil can be caused by either natural (sea waters and mineral) or anthropogenic factors (waste and post-industrial waste, mineral fertilizers). Salinization affects around 3.8 million ha in Europe. Most affected are Campania in Italy, the Ebro Valley in Spain, and the Great Alföld in Hungary, but also areas in Greece, Portugal, France, Slovakia and Austria (CEC 2006). Naturally saline soils cover only a small area of Poland. They can be found on areas which are reinforced by highly mineralized groundwater. They are accompanied by rare inland halophytes. Halophytes are a group of plants which grows on areas rich in readily soluble salts. According Siddikee et al. (2011), saline soils contain a high amount of soluble salts, primarily cations $\mathrm{Ca}^{2+}, \mathrm{Mg}^{2+}, \mathrm{Na}^{+}$and $\mathrm{K}^{+}$, salt of $\mathrm{SO}_{4}^{-2}, \mathrm{Cl}-, \mathrm{NO}^{-3}$ and $\mathrm{CO}_{3}^{-3}$. Sorption properties and exchangeable cations content play an important role in the process of leaching of nutrient components from the soil and determine the effectiveness of fertilization, what is of importance in plant nutrition processes (Bartkowiak and Długosz 2010). The level of saturation of the sorptive complex with base cations determines the fertility of soils and their resistance to chemical degradation (Paluszek 2014). According to Grigore et al. (2012), saline soils are poor in nutrients, but it is generally accepted that salt stress is the most important restrictive factor for plant growth in this type of habitats. In the last century a lot of natural salt meadows decreased their area as a result of e.g. site drainage, drying up of saline springs, change of water relations due to the lack of strict protection of the Natura 2000 sites. Soil monitoring on the protected areas should be a part of strategic scope of research. Saline and sodic landscapes can impact carbon and nutrient cycling, and organic matter decomposition. Available phosphorus is only a very small fraction of total $\mathrm{P}$ in the terrestrial ecosystems (less than 6\%). Many researchers have reported that the fractions and dynamics of $\mathrm{P}$ in soil also depend upon various soil characteristics such as $\mathrm{pH}$ (Liang et al. 2010; Lemanowicz 2013), organic matter concentrations (Xiao et al. 2012; Lemanowicz and Bartkowiak 2013). 
High salinity suppresses the phosphorus uptake by plant roots and reduces the available phosphorus by sorption processes. One of the indices of changes in the content of phosphorus in soil can be the measurement of the activity of soil phosphatases, especially phosphomonoesterases which take part in the process of mineralization of organic phosphorus (Lemanowicz and Krzyżaniak 2015).

The study was conducted in the naturally salt-affected grassland in the areas of Natura 2000 in central Poland. The primary objective of this study was to determine the distribution of the content of total and available phosphorus, availability factor of this macroelement and the activities of phosphomonoesterase of natural saline soil against its selected chemical properties.

\section{MATERIAL AND METHODS}

\section{Study area and soil sampling}

The soil was sampled in Ciechocinek (Poland) in the area of halophyte natural reserve, which was founded in 1963 on the area of 1.88 ha $\left(52^{\circ} 52^{\prime} \mathrm{N}\right.$; $18^{\circ} 46^{\prime}$ E; the Kuyavian-Pomeranian Province, central Poland) (Fig. 1).

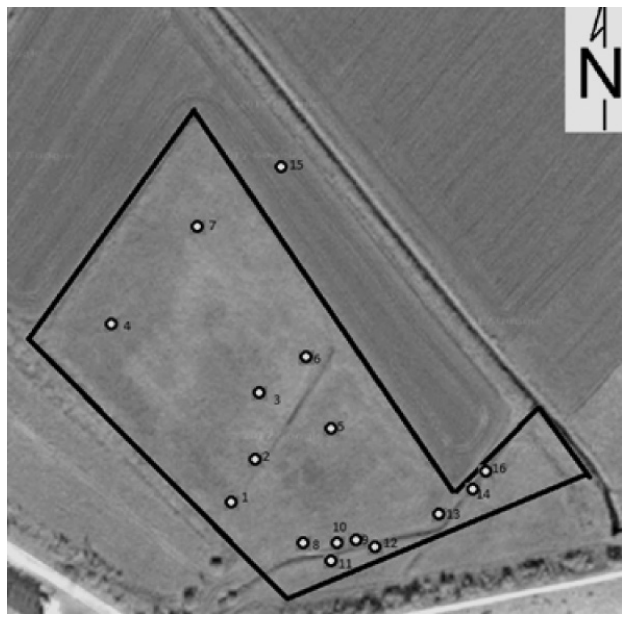

Fig. 1. Localization of the study area

The local climate is a typical temperate climate, with annual rainfall of about $500 \mathrm{~mm}$. The annual mean temperature of the study area is $8.1^{\circ} \mathrm{C}$. The reserve is situated on the complex of Vistula meadows and cropland. This habitat is inscribed on the list in Annex I of the Habitats Directive. Vertical seepage of mineral water causes salinity of these areas. The water is in contact with the Zechstein rocks salt structures up to groundwater level. As a result of the drainage of the valley (in the $50 \mathrm{~s}$ and $60 \mathrm{~s}$ of the $20^{\text {th }}$ century) the water level fell by 
more than $1 \mathrm{~m}$. This led to the almost complete disappearance of the salt areas. Today, it is a refuge habitat of rare species of halophytes in Poland, particularly Aster tripolium and Salicornia europaea which, apart from Ciechocinek, do not grow in inland areas impacted by mineral brines. Through the halophyte reserve passes a shallow ditch draining storm water or the brine directly flowing from the neighbouring graduation towers (unique in Europe, wooden structures from the $19^{\text {th }}$ century, built to thicken the brine in salt production process). Since the beginning of the $21^{\text {st }}$ century, an extensive use of the land reserve began (mowing and grazing) and a ditch valve to discharge storm water from the graduation towers was installed. Halophilous vegetation began to spread in the reserve and small patches of Salicornia europaea were first seen outside the ditch.

A total of sixteen soil samples were collected (designated as site from 1 to 7 , site from 11 to 14 and site 16 nearest to the drainage ditch; site 15 in agricultural area, respectively) during the summer of 2014. In agricultural area (site 15) winter wheat was cultivated, NPK fertilization was applied at the following rates: 154 $\mathrm{kg} \mathrm{ha}^{-1} \mathrm{~N},\left(\mathrm{NH}_{4} \mathrm{NO}_{3}\right), 38.37 \mathrm{~kg} \mathrm{ha}^{-1} \mathrm{P}\left(\right.$ as $\left.\left(\mathrm{NH}_{4}\right)_{3} \mathrm{PO}_{4}\right)$ and $99.6 \mathrm{~kg} \mathrm{ha}^{-1} \mathrm{~K}$ (as $\mathrm{KCl}$, $60 \%$ of K). Triplicate soil samples were collected from the $0-20-\mathrm{cm}$ depth in each site. According to the international soil classification WRB (IUSS Working Group WRB 2015), most of them can be referred to as Fluvic Gleysols (Salic, Sodic).

\section{Physiochemical parameters of the soil}

Chemical analyses were performed on air-dried and sieved samples $(<2 \mathrm{~mm})$. Each sample was analysed in triplicate. In the adequately prepared soil samples the following were assayed: $\mathrm{pH}$ in $0.01 \mathrm{M} \mathrm{CaCl}_{2}$ measured potentiometrically, total organic carbon (TOC) was determined with the TOC FORMACTS ${ }^{\mathrm{TM}}$ analyser Primacs provided by Skalar, the exchangeable cations of $\mathrm{Ca}, \mathrm{Mg}, \mathrm{Na}, \mathrm{K}$ in the extract of $\mathrm{BaCl}_{2}$ (PN-EN ISO 11260: 2011) using the method of atomic absorption spectrometry and emission spectrometry applying the spectrophotometer Philips PU 9100, electrical conductivity $\left(\mathrm{EC}_{1: 5}\right)$ was determined in deionized water in a 1:5 soil: water extract. The content of total phosphorus (TP) was determined as described by Mehta et al. (1954), by treating soil with concentrated $\mathrm{HCl}$ and then with $0.5 \mathrm{M} \mathrm{NaOH}$. After mixing, the extracts were mineralized with a respective mixture of concentrated acids: nitric acid (V), perchloric acid (VII) and sulphuric acid (VI) at the ratio of 10:1:4. Available phosphorus (AP) with the Egner-Riehm method - DL (PN-R-04023: 1996). The phosphorus content was calorimetrically defined by measuring the intensity of molybdenum blue and $\mathrm{SnCl}_{2}$ reaction. The content of AP for soil is based on the available P status of the soil, which has been classified depending on the $\mathrm{P}$ concentration. The availability factor (AF\%) for phosphorus, as suggested by Xiao et al. (2012), was applied for this purpose. It is expressed as follows: $\mathrm{AF} \%=(\mathrm{AP} / \mathrm{TP})^{*} 100$. 


\section{Biochemical analyses}

Prior to enzyme activity analyses, soil samples were thawed at $4^{\circ} \mathrm{C}$ until soil enzymatic analysis was performed within 2 weeks of sampling and soil moisture was determined after drying at $105^{\circ} \mathrm{C}$ for $48 \mathrm{~h}$.

The activity of alkaline (AlP) [E.C. 3.1.3.1] and acid (AcP) [E.C. 3.1.3.2] phosphatase with the Tabatabai and Bremner method (1969). It is based on the colorimetric assaying of released substrate: p-nitrophenylphosphate after the incubation of soil with of MUB (Modified Universal Buffer) at $\mathrm{pH} 6.5$ for acid phosphatase and $\mathrm{pH} 11.0$ for alkaline phosphatase samples for $1 \mathrm{~h}$ at the temperature of $37^{\circ} \mathrm{C}$.

\section{Statistical analyses}

Classical statistics was used to study tendencies (mean, median) and the variability (standard deviation $\mathrm{SD}$, coefficient of variation, minimum and maximum) of the sample population. $\mathrm{CV} \%=(\mathrm{SD} / \mathrm{Mean}) * 100$. Coefficient of variation (CV) was used to reflect the degree of discrete distribution of different TOC, TP, AP exchangeable cations contents and activity of phosphatase, and to indicate indirectly the activeness of the selected element in the examined environment. Values where $0-15 \%, 16-35 \%$, and $>36 \%$ indicate low, moderate, or high variability, respectively (Wilding 1985). The descriptive statistical analysis, such as Pearson's correlation coefficients were calculated using STATISTICA 7.0. All effects were considered significant at the $p<0.05$ land $p<0.001$ level.

Principal component analysis (PCA) was applied using data for soil phosphatase activities, content phosphorus and soil physical-chemical properties. The first two principal components (PC1 and $\mathrm{PC} 2$ ) were selected for further interpretation of the results. Hierarchical cluster analysis (CA) with Ward's method (1963) was used to identify the similarity groups between the sampling 16 sites.

All analytical measurements were performed with three replications. Arithmetic mean values are shown in tables.

\section{RESULTS AND DISCUSSION}

\section{Soil $p H$, electrical conductivity and total organic carbon}

Soil $\mathrm{pH}$ in $0.01 \mathrm{M} \mathrm{CaCl}_{2}$ range is limited and varies from 4.45 to 7.40 (Table 1) with a mean value of $6.33 \pm 1.12$ (Table 3). Soils from sites 1 to 7 were acidic (Table 1), and sites from 8 to 16 were slightly alkaline. This parameter is extremely important as it influences the surface charge magnitude of soil colloids, which is reflected in the cations exchangeable capacity. Then in the soil the balance between the content of exchangeable cations and the amount of 
soil minerals weathering products in soil solution is established (Crabtree 1986). Electrical conductivity $\left(\mathrm{EC}_{1: 5}\right.$ ) ranges from $1.89 \mathrm{dS} \mathrm{m}^{-1}$ to $15.18 \mathrm{dS} \mathrm{m}^{-1}$ and has arithmetical mean of $6.67 \pm 3.71 \mathrm{dS} \mathrm{m}^{-1}$ (Table 3 ). In the study conducted by Piernik and Hulisz (2011), the soil salinity levels of natural saline were between $1.58-38.5 \mathrm{dS} \mathrm{m}^{-1}$. Electrical conductivity is a soil parameter that indicates indirectly the total concentration of soluble salts and is a direct measurement of salinity (Mahmood et al. 2013). $\mathrm{EC}_{1.5}$ was slight and very strong in most of the samples $\left(<2 \mathrm{dS} \mathrm{m}^{-1}\right)$ and has only one low value $\left(1.89 \mathrm{dS} \mathrm{m}^{-1}\right)$ (Table 1$)$.

TABLE 1. PH IN CACL $\mathrm{C}_{2}$, SALINITY ( $\mathrm{EC}_{1: 5}$ ) AND EXCHANGEABLE CATIONS IN THE SURFACE SAMPLES

\begin{tabular}{|c|c|c|c|c|c|c|c|}
\hline \multirow{2}{*}{$\begin{array}{l}\text { Sampling } \\
\text { Sites }\end{array}$} & \multirow{2}{*}{$\begin{array}{c}\text { Clay } \\
\%\end{array}$} & \multirow{2}{*}{$\begin{array}{c}\mathrm{pH} \\
\mathrm{CaCl}_{2}\end{array}$} & \multirow{2}{*}{$\begin{array}{l}\mathrm{EC}_{1: 5} \\
\mathrm{dS} \mathrm{m}\end{array}$} & $\mathrm{Ca}^{2+}$ & $\mathrm{Mg}^{2+}$ & $\mathrm{Na}^{+}$ & $\mathrm{K}^{+}$ \\
\hline & & & & \multicolumn{4}{|c|}{$\mathrm{mmol}(+) \mathrm{kg}^{-1}$} \\
\hline 1 & 1.05 & 5.21 & 2.47 & 4.26 & 0.263 & 0.339 & 0.253 \\
\hline 2 & 0.89 & 6.39 & 2.54 & 5.74 & 0.261 & 0.450 & 0.145 \\
\hline 3 & 2.06 & 5.23 & 2.31 & 3.57 & 0.219 & 1.059 & 0.150 \\
\hline 4 & 3.25 & 4.66 & 1.89 & 3.11 & 0.196 & 1.431 & 0.194 \\
\hline 5 & 8.41 & 5.14 & 2.59 & 13.30 & 0.183 & 2.283 & 0.247 \\
\hline 6 & 7.72 & 4.45 & 2.11 & 8.38 & 0.004 & 0.517 & 0.318 \\
\hline 7 & 13.08 & 5.29 & 2.68 & 15.57 & 0.108 & 1.395 & 0.217 \\
\hline 8 & 4.62 & 7.19 & 9.25 & 14.55 & 0.104 & 13.87 & 0.370 \\
\hline 9 & 5.59 & 7.35 & 10.17 & 16.39 & 0.915 & 14.12 & 1.025 \\
\hline 10 & 4.65 & 7.36 & 10.87 & 13.96 & 0.701 & 3.654 & 0.901 \\
\hline 11 & 15.35 & 7.40 & 9.89 & 19.50 & 0.187 & 3.901 & 1.002 \\
\hline 12 & 3.06 & 7.39 & 14.48 & 6.92 & 0.100 & 14.41 & 0.626 \\
\hline 13 & 4.39 & 7.14 & 13.62 & 22.74 & 0.245 & 1.633 & 0.772 \\
\hline 14 & 10.78 & 7.30 & 4.75 & 9.19 & 0.179 & 14.12 & 0.687 \\
\hline 15 & 8.73 & 6.56 & 2.01 & 19.27 & 0.026 & 0.557 & 0.681 \\
\hline 16 & 5.62 & 7.31 & 15.18 & 16.49 & 0.586 & 16.11 & 0.957 \\
\hline
\end{tabular}

The total organic carbon content in the soil ranged from 3.910 to 7.780 $\mathrm{g} \mathrm{kg}^{-1}$ (Table 2) (with a mean value of $6.204 \pm 1.413$ ) (Table 3), and the lowest content was recorded in the soil collected from site from 1 to 7 (Table 2). According to the literature, organic matter as an ingredient of soil (derived from various sources) increases its sorption capacity, the content of base cations and the degree of saturation of the sorption complex with basic cations, decreases hydrolytic acidity and increases soil $\mathrm{pH}$ (Caravaca et al. 1999; Frouz et al. 2006; Bielińska and Mocek 2010). The analysis of correlation confirmed a significant correlation between organic carbon and $\mathrm{pH}$ of the soil $(r=0.975, p<0.01)$ and the content of cations of sodium $(r=0.696, p<0.05)$ and potassium $(r=0.761$, $p<0.05$ ) (Table 6). Similar results were obtained by Ross et al. $(1991,2008)$ and Peinemann et al. (2000) in their research. 
TABLE 2. THE CONTENT OF TOTAL ORGANIC CARBON (TOC), TOTAL PHOSPHORUS (TP), AVAILABLE PHOSPHORUS (AP), ACTIVITY OF ALKALINE (ALP) AND ACID (ACP) PHOSPHATASE AND THE AVAILABILITY FACTOR (AF) AND ENZYMATIC INDEX OF SOIL PH (ALP/ACP)

\begin{tabular}{|c|c|c|c|c|c|c|c|}
\hline \multirow{2}{*}{$\begin{array}{l}\text { Sampling } \\
\text { Sites }\end{array}$} & \multirow{2}{*}{$\begin{array}{l}\text { TOC } \\
\mathrm{g} \mathrm{kg}^{-1}\end{array}$} & \multirow{2}{*}{$\begin{array}{c}\text { TP } \\
\mathrm{g} \mathrm{kg}^{-1}\end{array}$} & \multirow{2}{*}{$\begin{array}{c}\mathrm{AP} \\
\mathrm{g} \mathrm{kg}^{-1}\end{array}$} & \multirow{2}{*}{$\begin{array}{c}\mathrm{AF} \\
\%\end{array}$} & AlP & AcP & \multirow{2}{*}{$\mathrm{AlP} / \mathrm{AcP}$} \\
\hline & & & & & \multicolumn{2}{|c|}{$\mathrm{mM} \mathrm{pNP} \mathrm{kg}{ }^{-1} h^{-1}$} & \\
\hline 1 & 4.61 & 0.519 & 0.0152 & 2.928 & 0.677 & 1.429 & 0.47 \\
\hline 2 & 6.35 & 0.480 & 0.0191 & 3.680 & 0.795 & 1.209 & 0.66 \\
\hline 3 & 4.89 & 0.538 & 0.0163 & 3.030 & 0.601 & 1.198 & 0.50 \\
\hline 4 & 4.25 & 0.522 & 0.0178 & 3.410 & 0.612 & 1.288 & 0.48 \\
\hline 5 & 4.65 & 0.546 & 0.0164 & 3.004 & 0.632 & 1.294 & 0.49 \\
\hline 6 & 3.91 & 0.492 & 0.0159 & 3.232 & 0.526 & 1.419 & 0.37 \\
\hline 7 & 4.80 & 0.429 & 0.0152 & 3.543 & 0.601 & 1.308 & 0.46 \\
\hline 8 & 7.39 & 0.319 & 0.0103 & 3.229 & 1.058 & 1.395 & 0.76 \\
\hline 9 & 7.41 & 0.348 & 0.0098 & 2.816 & 1.171 & 1.426 & 0.82 \\
\hline 10 & 7.33 & 0.348 & 0.0108 & 3.103 & 1.094 & 1.419 & 0.77 \\
\hline 11 & 7.27 & 0.307 & 0.0094 & 3.062 & 1.144 & 1.528 & 0.75 \\
\hline 12 & 7.78 & 0.312 & 0.0087 & 2.788 & 1.209 & 1.556 & 0.78 \\
\hline 13 & 6.41 & 0.382 & 0.0107 & 2.801 & 0.958 & 1.358 & 0.71 \\
\hline 14 & 7.21 & 0.369 & 0.0119 & 3.225 & 1.137 & 1.496 & 0.76 \\
\hline 15 & 7.60 & 0.377 & 0.0198 & 5.252 & 1.098 & 1.567 & 0.70 \\
\hline 16 & 7.41 & 0.357 & 0.0099 & 2.773 & 1.207 & 1.389 & 0.77 \\
\hline
\end{tabular}

TABLE 3. STATISTICAL PARAMETERS OF THE SELECTED SOIL PROPERTIES

\begin{tabular}{cccccccc}
\hline Parameters & $(n)$ & Min & Max & Mean & Median & SD & CV \% \\
\hline Clay & 16 & 0.89 & 15.35 & 6.20 & 5.12 & 4.20 & 67.75 \\
$\mathrm{pH} \mathrm{CaCl}{ }_{2}$ & 16 & 4.45 & 7.40 & 6.33 & 6.85 & 1.12 & 17.76 \\
$\mathrm{EC}$ & 16 & 1.89 & 15.18 & 6.67 & 3.71 & 5.05 & 75.78 \\
$\mathrm{Ca}^{2+}$ & 16 & 3.11 & 22.74 & 12.05 & 13.63 & 6.24 & 51.77 \\
$\mathrm{Mg}^{2+}$ & 16 & 0.004 & 0.915 & 0.267 & 0.191 & 0.251 & 93.95 \\
$\mathrm{Na}^{+}$ & 16 & 0.339 & 16.11 & 5.615 & 1.958 & 6.304 & 112.2 \\
$\mathrm{~K}^{+}$ & 16 & 0.145 & 1.025 & 0.534 & 0.498 & 0.330 & 61.78 \\
$\mathrm{TOC}$ & 16 & 3.910 & 7.780 & 6.204 & 6.810 & 1.413 & 22.77 \\
$\mathrm{TP}$ & 16 & 0.307 & 0.546 & 0.415 & 0.379 & 0.086 & 20.93 \\
$\mathrm{AP}$ & 16 & 0.009 & 0.020 & 0.014 & 0.013 & 0.003 & 27.67 \\
$\mathrm{AlP}$ & 16 & 0.526 & 1.209 & 0.907 & 1.008 & 0.260 & 28.69 \\
$\mathrm{AcP}$ & 16 & 1.198 & 1.567 & 1.392 & 1.407 & 0.112 & 8.095 \\
$\mathrm{AF}$ & 16 & 2.773 & 5.252 & 3.242 & 3.164 & 0.600 & 18.51 \\
$\mathrm{AlP} / \mathrm{AcP}$ & 16 & 0.370 & 0.820 & 0.640 & 0.705 & 0.149 & 23.41 \\
\hline
\end{tabular}

$\mathrm{SD}$ - standard deviation, CV [\%] - coefficient of variation 
TABLE 4. RELATIONSHIP BETWEEN SELECTED SOIL PROPERTIES

$(P<0.05, P<0.001 *)$

\begin{tabular}{|c|c|c|c|c|}
\hline \multicolumn{2}{|c|}{ Variables } & \multirow{2}{*}{ Equation } & \multirow{2}{*}{$r$} & \multirow{2}{*}{$r^{2}$} \\
\hline Dependent & Independent & & & \\
\hline Total organic carbon & Alkaline phosphatase & $y=5.2902 x+1.403$ & 0.974 & 0.950 \\
\hline Alkaline phosphatase & Available phosphorus & $y=-56.710 x+1.677$ & -0.691 & 0.447 \\
\hline $\mathrm{pH} \mathrm{CaCl}$ & Available phosphorus & $y=-231.595 x+9.479$ & -0.779 & 0.607 \\
\hline $\mathrm{pH} \mathrm{CaCl}{ }_{2}$ & Alkaline phosphatase & $y=4.2177 x+2.508$ & 0.957 & 0.952 \\
\hline $\mathrm{pH} \mathrm{CaCl}_{2}$ & Total organic carbon & $y=0.777 x+1.515$ & $0.975^{*}$ & 0.952 \\
\hline $\mathrm{Na}^{+}$ & Total organic carbon & $y=3.107 x-13.665$ & 0.696 & 0.484 \\
\hline $\mathrm{K}^{+}$ & Total organic carbon & $y=0.177 x-0.568$ & 0.761 & 0.579 \\
\hline $\mathrm{Na}^{+}$ & Available phosphorus & $y=-1216 x+22.136$ & -0.725 & 0.525 \\
\hline $\mathrm{K}^{+}$ & Available phosphorus & $y=-60.34 x+1.380$ & -0.709 & 0.502 \\
\hline $\mathrm{Ca}^{2+}$ & Alkaline phosphatase & $y=12.19 x+0.994$ & 0.508 & 0.258 \\
\hline $\mathrm{Na}^{+}$ & Alkaline phosphatase & $y=17.57 x-10.334$ & 0.726 & 0.527 \\
\hline $\mathrm{K}^{+}$ & Alkaline phosphatase & $y=1.081 x-0.446$ & 0.852 & 0.727 \\
\hline $\mathrm{EC}_{1: 5}$ & Available phosphorus & $y=-1191 x+22.85$ & -0.884 & 0.782 \\
\hline $\mathrm{EC}_{1: 5}$ & Alkaline phosphatase & $y=14.793 x-6.749$ & 0.761 & 0.579 \\
\hline $\mathrm{EC}_{1: 5}$ & $\mathrm{Na}^{+}$ & $y=0.523 x+3.737$ & 0.651 & 0.425 \\
\hline $\mathrm{EC}_{1: 5}$ & $\mathrm{~K}^{+}$ & $y=11.51 x+0.526$ & 0.750 & 0.563 \\
\hline $\mathrm{EC}_{1: 5}^{1: 5}$ & $\mathrm{AF}$ & $y=-4.287 x+20.577$ & -0.508 & 0.258 \\
\hline $\mathrm{AlP} / \mathrm{AcP}$ & Available phosphorus & $y=-26.68 x+1.002$ & -0.668 & 0.446 \\
\hline $\mathrm{AlP} / \mathrm{AcP}$ & $\mathrm{pH} \mathrm{CaCl}$ & $y=0.131 x-0.188$ & 0.981 & 0.964 \\
\hline $\mathrm{AlP} / \mathrm{AcP}$ & $\mathrm{Na}^{+}$ & $y=0.016 x+0.547$ & 0.694 & 0.482 \\
\hline $\mathrm{AlP} / \mathrm{AcP}$ & $\mathrm{K}^{+}$ & $y=0.358 x+0.448$ & 0.789 & 0.623 \\
\hline
\end{tabular}

TABLE 5. VALUES OF THE THREE EXTRACTED FACTOR LOADINGS FOR 13 ELEMENTS

\begin{tabular}{ccc}
\hline Parameters & \multicolumn{2}{c}{ Component matrix } \\
\cline { 2 - 3 } TOC & PC1 & PC2 \\
TP & $0.929^{*}$ & 0.205 \\
$\mathrm{AP}$ & $-0.934^{*}$ & -0.209 \\
$\mathrm{pH}$ & $-0.837^{*}$ & 0.411 \\
$\mathrm{AlP}$ & $0.957^{*}$ & 0.082 \\
$\mathrm{AcP}$ & $0.965^{*}$ & 0.173 \\
$\mathrm{Ca}^{2+}$ & 0.616 & 0.470 \\
$\mathrm{Mg}^{2+}$ & 0.582 & 0.327 \\
$\mathrm{Na}^{+}$ & 0.482 & -0.487 \\
$\mathrm{~K}^{+}$ & $0.751^{*}$ & -0.264 \\
$\mathrm{EC}$ & $0.894^{*}$ & 0.060 \\
$\mathrm{AF}$ & $0.868^{*}$ & -0.305 \\
$\mathrm{AlP} / \mathrm{AcP}$ & -0.229 & $0.918^{*}$ \\
Variation $(\%)$ & $0.941^{*}$ & 0.091 \\
Eigenvalue & 63.82 & 14.45 \\
\hline
\end{tabular}

* statistically significant 


\section{The exchangeable cations}

In the analysed soil samples a series of quantitative cations of basic character is as follows: $\mathrm{Ca}^{2+}>\mathrm{Na}^{+}>\mathrm{K}^{+}>\mathrm{Mg}^{2+}$. Also in the studies of Lemanowicz and Krzyżaniak (2015) in salt-affected Mollic Gleysols in direct surroundings of the graduation towers in Inowrocław (Poland), and Kobierski et al.'s (2011) research concerning soil of the Drawskie Lakeland, calcium was the dominant cation in the sorption complex. Whereas in the research of Piernik and Hulisz (2011) in natural saline grasslands in the villages and meadows in the valley of river, cations were arranged in the following order: $\mathrm{Na}^{+}>\mathrm{Ca}^{2+}>\mathrm{K}^{+}>\mathrm{Mg}^{2+}$. The difference in exchangeable bases between not saline soils and saline soils are mainly in cation ratios. Not saline soils are: $\mathrm{Ca}^{2+}>\mathrm{Mg}^{2+}>\mathrm{K}^{+}>\mathrm{Na}^{+}$. The analysis of the contents of individual cations in sorption complex showed a clear dominance of calcium ions. The contents of this cation ranged from 3.11 to 22.74 mmol(+) $\mathrm{kg}^{-1}$ (Table 3). Large amounts of calcium cations are characteristic of alkaline soils. In the analysed samples such a relationship was also observed. Second after calcium in terms of the number of occurrence in the analysed soil sorption complex were sodium ions. The concentration of $\mathrm{Na}^{+}$was in a wide range of from 0.339 to $16.11 \mathrm{mmol}(+) \mathrm{kg}^{-1}$ and average $5.615 \mathrm{mmol}(+) \mathrm{kg}^{-1}$. Please note that sodium cations are one of the most easily leached cations from the soil by rain water and their large quantities in surface profiles of soil levels are only observed when there is a continuous supply of sodium compounds into the soil from specific sources (Czerwiński 1996; Kwasowski 1996; Ochman and Jezierski 2011). Increased content of ions in the analysed samples from 8 to 14 and the sample no 16 were caused by the close proximity of the ditch-powered water discharged from the nearby graduation towers. The high content of sodium ions in water extracts of soils indicates a violation of the natural system of base cations in the soil solution, which for most soils of a temperate climate are dominated by calcium, then by magnesium and potassium. This allows one to conclude that the increased salinity significantly modifies the quantitative and qualitative composition of soil solutions. But according to Rengasamy and Olsson (1991), soils high in organic matter are generally resistant to Na adsorption and rarely display sodic behaviour, largely due to increased hydrophobicity caused by the presence of hydrophobic organic compounds. The calculated correlation coefficients confirmed a significant correlation between $\mathrm{Na}^{+}$ions $(r=0.651, p<0.05)$ and $\mathrm{K}^{+}(r=0.750, p<0.05)$ and the conduction of electrolyte (Table 4). Similar results were obtained by Czerwiński (1996) and Ochman et al. (2011) in the analysed soils fed by post-floatation waters and by Krzyżaniak and Lemanowicz (2013) in saline soils of the Kujawy region. In the analysed samples, similarly to the soils studied by Piernik and Hulisz (2011), the lowest $\mathrm{Mg}^{2+}$ ions were observed, its content was in a narrow range of from 0.004 to $0.915 \mathrm{mmol}(+) \mathrm{kg}^{-1}$. 


\section{The content of phosphorus}

The total phosphorus content was in the range of $0.307-0.546 \mathrm{~g} \mathrm{~kg}^{-1}$ (mean $0.415 \mathrm{~g} \mathrm{~kg}^{-1} \pm 0.086$ ), while the soil available phosphorus content ranged from $0.009-0.020 \mathrm{~g} \mathrm{~kg}^{-1}$ (mean value $0.014 \mathrm{~g} \mathrm{~kg}^{-1} \pm 0.003$ ) (Table 3). According to PN-R-04023 (1996), this soil classifies as V class with a very low content of AP. According to Lemanowicz and Krzyżaniak (2015), a constant supply of a large amount of cations and anions from the structures can, as a result, lead to permanent changes in the chemical properties of soils, making direct surroundings of the graduation towers. In fact, aerosol production is a natural process deriving from the interaction of wind stress graduation towers. Soil available phosphorus content had significant negative correlation with $\mathrm{pH} \mathrm{CaCl}_{2}$ value $(r=-0.779, p<0.05)$ (Table 4). There is a considerable evidence in the literature (Lakhdar et al. 2009; Krzyżaniak and Lemanowicz 2013) that $\mathrm{pH}$ can affect forms and dynamics of this nutrient in soil. At $\mathrm{pH}>7$ phosphorus is precipitated by $\mathrm{Ca}^{2+}$ and $\mathrm{Mg}^{2+}$.

Based on the present results of the content of total and available phosphorus, there was calculated availability factor $\mathrm{AF}(\%)$ for phosphorus. In the soil investigated, the $\mathrm{AF}$ value ranged from $2.773 \%$ to $5.252 \%$ (Table 3 ). When the value of the AF ratio is higher than $2 \%$ it indicates that soil $\mathrm{P}$ was sufficient for plant growth in this environment. According to Qadir and Schubert (2002) and Pan et al. (2013), most saline soils are adequately supplied with phosphorus. Concentration of $\mathrm{Na}^{+}$ions may result in more soluble $\mathrm{Na}_{3} \mathrm{PO}_{4}$ formed. In this study, the concentration of $\mathrm{Na}^{+}$ions increased with an increase in salinity (positive correlation), which leads to increased AP content in soils. The highest value of the $\mathrm{AF}(5.252 \%)$ was obtained in the soil of the site 15 (arable soil) (Table 2). It could be due to the inflow of total organic carbon (TOC), which stimulates the activity of phosphatases, which speeds up the P cycling.

\section{Soil alkaline and acid phosphatase}

The activities of both alkaline and acid phosphatase are closely related to soil $\mathrm{pH}$, with acid phosphatase dominating in acid soils, and alkaline phosphatase in alkaline soils (Wang et al. 2011). According to Zhang et al. (2014), soil pH also affects the activity of enzymes due to the $\mathrm{pH}$ sensitivity of amino acid functional groups that alter the conformational and chemical changes of amino acids essential for binding and catalysis. According to Wilding's (1985) classification, the CV values of soil alkaline phosphatase activities was relatively low $(8.095 \%)$, whereas those of acid phosphatase activities (49-53\%) were at the medium level.

The reduction of enzyme activity in saline soils could be due to the osmotic dehydration of the microbial cells that liberate intracellular enzymes. Soil alkaline phosphatase activity had the same $(28.69 \%$ - moderate $)$ variability as the available phosphorus (27.67\%) (CVs Table 3). 
Correlation analysis among phosphatase activities soil and chemical properties indicated several significant trends (Table 4). Correlation analysis showed that there was significant correlation between the total organic carbon and the activities of soil alkaline phosphatase $(r=0.974, p<0.05)$, indicating that an increase in soil enzymatic activity is a consequence of increased OM (organic matter) (Siddikee et al. 2011). Comparing soils sites from 1 to 7 showed much lower enzyme activities than in soils of sites from 8 to 16 (maximum alkaline and acid phosphatase activities were observed in soils from the sites where halophytic vegetation was found) (Table 2). According to Rao et al. (1996), organic matter has ameliorative influence on biological activity in salt-affected soils and inhibition of alkaline and acid phosphatase activities in soil sites from 1 to 7 might be due to the lower bacterial population and activity under the limited carbonaceous substrates. The results indicated that $\mathrm{pH} \mathrm{CaCl}$ value was positively correlated with alkaline phosphatase activity at an extremely significant level $(r=0.975, p<0.05)$ but not with acid phosphatase activity. In the study of Wang et al. (2011) alkaline phosphatase activity was more than twice as high as acid phosphatase activity, mainly because soil $\mathrm{pH}$ was in the range of 7.2-7.7. Our result agrees with earlier reports (Siddikee et al. 2011) that alkaline phosphatase activity was not predominant in neutral or alkaline soils. Zhang et al. (2014) states that with the soil $\mathrm{pH}$ varying from 7.38 to 10.00, AlP activities decreased exponentially. According to Tripathi et al. (2007), phosphatase activity responded more to $\mathrm{pH}$ than to the differences in soil salinity. Soil $\mathrm{EC}_{1: 5}$ had a significant positive correlation with alkaline phosphatase activity $(r=0.761$, $p<0.05)$. The influence of soil $\mathrm{EC}_{1: 5}$ on enzyme activities might be that the level of soil salt had some impacts on enzyme configuration and formation of its activity centre. Changes in salinity also have the potential to impact extracellular enzyme activity by influencing molecular stability and protein confirmation states (Lakhdar et al. 2009). Soil available phosphorus content had a significant $(r=-0.884, p<0.05)$ negative correlation with the $\mathrm{EC}_{1: 5}$ value. In saline soils the availability of phosphorus depends on the length of the roots of the plants and the negative effect of chlorides on the absorption of $\mathrm{P}$ by the roots. Alkaline reaction is usually modified by the phosphorus balance, which in those soils undergoes retrograde processes transforming into sparingly soluble phosphates.

The AlP/AcP ratio of the soil profiles falls within the range of $0.370-0.820$ (Table 3). In most cases the values exceed 0.50 (site 2 and sites from 8 to 16) (Table 2), which in the case of the soil analysed was confirmed with the potentiometer method of $\mathrm{pH}$ in $\mathrm{CaCl}_{2}$ measurement, which is connected with the fact that phosphomonoesterases are the enzymes which are one of the most sensitive indicator of change of soil pH (Dick et al. 2000, Krzyżaniak and Lemanowicz 2013).

A significant statistical negative correlation between the content of available phosphorus and the activity of alkaline phosphatase in soil was recorded $(r=-0.691 ; p<0.05)$. Negative correlation between alkaline phosphatase activi- 
ty and available phosphorus content showed that alkaline phosphatase activity is higher in the soil deficient in soil phosphorus. No significant correlations between available $\mathrm{P}$ and acid phosphatase activities were found, which suggests that the AlP was the adequate parameter defining the soils analysed, unlike the activity of acid phosphatase.

Soil alkaline phosphatase activities showed significant positive correlations with exchangeable $\mathrm{Na}^{+}(r=0.726, p<0.05)$ and $\mathrm{Ca}^{2+}(r=0.508, p<0.05)$ content.

Soil enzymes are an indicator of soil biological activity because, according to Koper et al. (2008), Siddikee et al. (2011), Lemanowicz (2013), Guan et al. (2014), enzymes are the products of vital activity, and their activities may reflect the states of soil biological metabolism and material transformation. Changes in salinity and alkalinity in the soil could impact the activities of soil phosphatase and the content of phosphorus.

A principal component analysis (PCA) was carried out taking into account the following thirteen parameters: $\mathrm{pH} \mathrm{CaCl}$, conductivity $\left(\mathrm{EC}_{1: 5}\right), \mathrm{Ca}^{2+}, \mathrm{Mg}^{2+}$, $\mathrm{Na}^{+}, \mathrm{K}^{+}, \mathrm{TOC}, \mathrm{TP}, \mathrm{AP}, \mathrm{AlP}, \mathrm{AcP}, \mathrm{AF}$ and AlP/AcP. The contribution of the two first axes to the total variability is $78.37 \%$ (Table 5) for all the soil samples: $63.82 \%$ for the first axis (PC1) and $14.45 \%$ for the second (PC2) (Fig. 2).

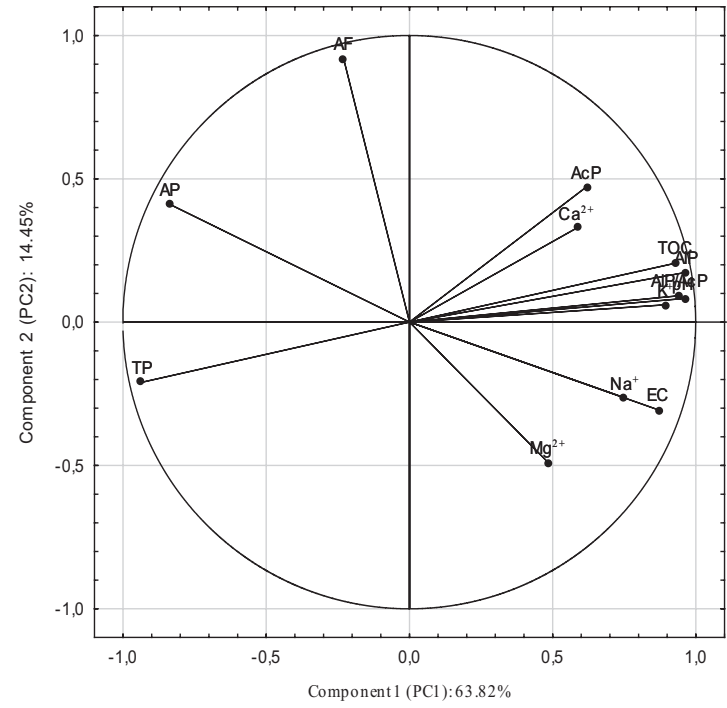

Fig. 2. Configuration of variables in the system of the first two axes of principal components PC1 and PC2 of the content of total organic carbon (TOC), total (TP) and available (AP) phosphorus, the activity alkaline (AlP) and acid (AcP) phosphatase and physical-chemical properties in soil (the exchangeable cations of $\mathrm{Ca}^{2+}, \mathrm{Mg}^{2+}, \mathrm{Na}^{+}, \mathrm{K}^{+}, \mathrm{pH} \mathrm{CaCl}, \mathrm{EC}$ )

PC1 is essentially characterized by 9 parameters (seven strongly correlated in the positive direction and two in the negative direction). Both TOC, $\mathrm{pH}, \mathrm{AlP}$ and AlP/AcP content had a major positive effect on PC1 $(>0.900)$, while soil 
TP and AP content had a negative effect on PC1 (>0.900) (Table 5). Moreover, $\mathrm{K}$ and $\mathrm{EC}_{1: 5}$ had a major positive effect on PC1 (>0.800). This association strongly suggests that these variables have a similar source. The distribution of these elements is mainly controlled by natural parent materials. The meaning of PC1 also agrees with the correlation coefficient between these variables. Alkaline phosphatase was located on the same site and near $\mathrm{pH}, \mathrm{EC}_{1: 5}$, TOC indicating that mainly the activity of this enzyme varies in terms of this soil property (as indicated by the length and direction of its vector). The non-significant correlation of acid phosphatase with the $1^{\text {st }} \mathrm{PC}$ implies that the enzyme is not associated with the total organic carbon and phosphorus. Factor 2 (PC2) is dominated by AF (available factor) accounting for $14.45 \%$ of the total variance. The obtained results demonstrate that statistical procedures towards classifying the content of phosphorus, activity phosphatase as groups in terms of relationship with soil some properties and identifying their probable origin in soil.

Cluster analysis (CA) is a statistical technique for classifying different soil samples by the relationships among measured variables representing soil properties. CA rendered a dendrogram as shown in Fig. 3A, grouping all 16 sampling sites into three statistically significant clusters.
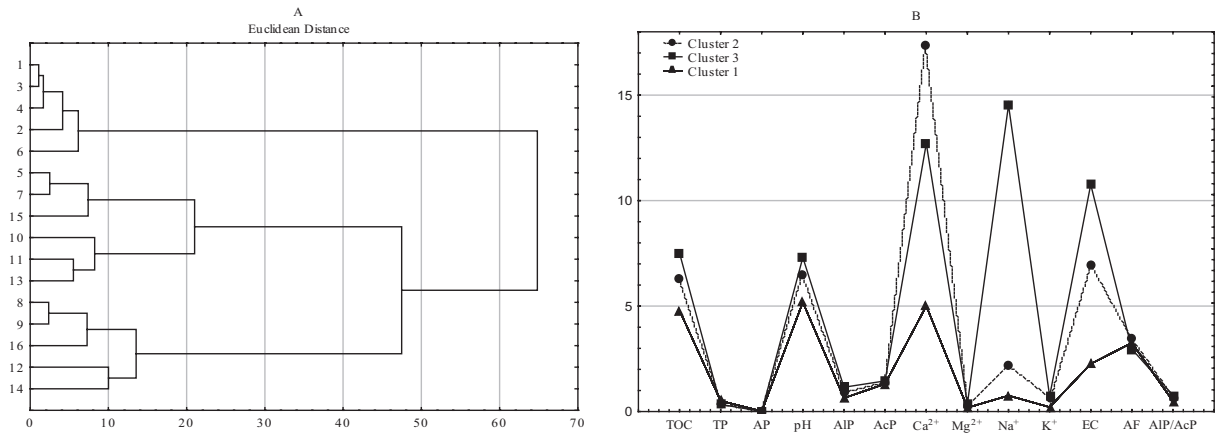

Fig. 3 A and B. Similarity dendrogram for sampling sites (1-16) (A) and a graph $k$-means for the study sites (B).

The most relevant in this study was Cluster 3, formed by most sampling sites nearest to the drainage ditch (cases $8,9,12,14,16$ ). These sampling sites were characterized by their higher sodium ions concentrations, electrical conductivity $\left(\mathrm{EC}_{1: 5}\right)$ and $\mathrm{pH}$ in $\mathrm{CaCl}_{2}$ (Fig. 3B), which might be related to the specific location of major tributaries of the saline. Five soil samples (cases 1, 2, 3, 4, 6) were included in Cluster 1 due to its lower alkaline phosphatase activity (AlP), total organic content and lower EC, pH and the exchangeable cations (Fig. 3B). 


\section{CONCLUSIONS}

1. In the analysed soil samples a series of quantitative cations of basic character is as follows: $\mathrm{Ca}^{2+}>\mathrm{Na}^{+}>\mathrm{K}^{+}>\mathrm{Mg}^{2+}$. Increased salinity has modified the qualitative and quantitative composition of the soil solution.

2. Correlation analysis confirmed the significant relationship between the conduction of the electrolytic soil and the content of sodium and potassium cations.

3. According to PN-R-04023 (1996), this soil classifies as class V with a very low content of AP but the availability factor for phosphorus (AF) value ranged from 2.773 to $5.252 \%$ indicating that soil $\mathrm{P}$ was sufficient for plant growth in this habitat.

4. The positive significant correlations among soil alkaline phosphatase and some physicochemical properties suggested that salinization had effects on these variables. Alkaline phosphatase may be used as indicators of soil quality in salinized grassland habitat Natura 2000.

5. Salinization on soil the content phosphorus and the activity phosphatases in grasslands habitat Natura 2000 in Ciechocinek (Poland) need further evaluation, which could provide rational management measures to promote their longterm sustainability.

\section{REFERENCES}

[1]. Bartkowiak, A., Długosz, J., 2010. The exchangeable cations in alluvial soils formed from calcareous sinter in the Unistawski Basin. Journal of Elementology, 15(3): 445-454. http://dx.doi.org/10.5601/jelem.2010.15.3.03

[2]. Bartula, M., Stojšić, V., Perić, R., Kitnæs, K.S., 2011. Protection of Natura 2000 habitat types in the Ramsar Site "Zasavica Special Nature Reserve" in Serbia. Natural Areas Journal, 31(4): 349-357. http://dx.doi.org/10.3375/043.031.0405

[3]. Bielińska, E.J., Mocek, A., 2010. Sorption properties and enzymatic activity of municipal park soils in regions of varying impact of anthropologic pressure. Journal of Research and Applications in Agricultural Engineering, 55(3): 20-23.

[4]. Caravaca, F., Lax, A., Albaladejo, J., 1999. Organic matter, nutrient contents and cation exchange capacity in fine fractions from semiarid calcareous soils. Geoderma 93(3-4): 161-176. doi:10.1016/S0016-7061(99)00045-2

[5]. CEC 2006. Commission Staff Working Document. Document Accompanying the Communication from the Commission to the Council, the European Parliament, the European Economic and Social Committee and the Committee of the Regions - Thematic Strategy for Soil Protection. Impact Assessment of the Thematic Strategy for Soil Protection. Commission of the European Communities, Brussels. SEC (2006) 620.

[6]. Council Directive 92/43/EEC of 21 May 1992 on the conservation of natural habitats and of wild fauna and flora (NATURA 2000).

[7]. Crabtree, R.W., 1986. Spatial distribution of solutional erosion. In: Solute Processes, S.T. Trudgill (ed.), John Wiley \& Sons: 326-361.

[8]. Czerwiński, Z., 1996. Salinity of water and soils in the Kujawy Region. Soil Science Annual, 47(3/4): 131-143. 
[9]. Dick, W.A., Cheng, L., Wang, P., 2000. Soil acid alkaline phosphatase activity as pH adjustment indicators. Soil Biology and Biochemistry, 32(13): 1915-1919.

http://dx.doi.org/10.1016/S0038-0717(00)00166-8

[10]. EN ISO 11260, 2011. Soil quality. Determination of effective cation exchange capacity and base saturation level using barium chloride solution.

[11]. Frouz, J., Elhottová, D., Kuráž, V., Šourková, M., 2006. Effects of soil macrofauna on other soil biota and soil formation in reclaimed and unreclaimed post mining sites: Results of a field microcosm experiment. Applied Soil Ecology, 33(3): 308-320.

doi:10.1016/j.apsoil.2005.11.001

[12]. Grigore, M.N., Villanueva, M., Boscaiu, M., Vicente, O., 2012. Do halophytes really require salts for their growth and development? An experimental approach. Notulae Scientia Biologicae, 4(2): 23-29. http://dx.doi.org/10.15835/nsb427606

[13]. Grodzinska-Jurczak, M., Cent, J., 2011. Expansion of nature conservation areas: problems with Natura 2000 implementation in Poland? Environmental Management, 47(1): 11-27. http://dx.doi.org/10.1007/s00267-010-9583-2

[14]. Guan, Zj., Luo, Q., Chen, X., Feng, Xw., Tang, Zx., Wei, W., Zheng, Yr., 2014. Saline soil enzyme activities of four plant communities in Sangong River basin of Xinjiang, China. Journal of Arid Land, 6(2): 164-173. http://dx.doi.org/10.1007/s40333-013-0223-6

[15]. IUSS Working Group WRB. 2015. World Reference Base for Soil Resources 2014, update 2015 International soil classification system for naming soils and creating legends for soil maps. World Soil Resources Reports No. 106. FAO, Rome.

[16]. Kobierski, M., Długosz, J., Bartkowiak, A., 2011. Sorption complex of selected soils of the Drawskie Lakeland. Journal of Elementology, 16(3): 397-405.

http://dx.doi.org/10.5601/jelem.2011.16.3.05

[17]. Koper, J., Piotrowska, A., Siwik-Ziomek, A., 2008. Dehydrogenase and invertase activities in a rusty soil in the neighbourhood of the Wtoctawek nitrogen plant ,Anwil”. Proceedings ECOpole 2(1): 197-202.

[18]. Krzyżaniak, M., Lemanowicz, J., 2013. Enzymatic activity of the Kuyavia Mollic Gleysols (Poland) against their chemical properties. Plant, Soil and Environment, 59(8): 359-365.

[19]. Kwasowski, W., 1996. Soils salinity and composition of readily soluble salts in soils in the vicinity of Thermal Electric Power Station Siekierki. Soil Science Annual, 47: 145-152.

[20]. Lakhdar, A., Rabhi, M., Ghnaya, T., Montemurro, F., Jedidi, N., Abdelly, Ch., 2009. Effectiveness of compost use in salt-affected soil. Journal of Hazardous Materials, 171(1-3): 29-37. http://dx.doi.org/10.1016/j.jhazmat.2009.05.132

[21]. Lemanowicz, J., 2013. Mineral fertilization as a factor determining selected sorption properties of soil against the activity of phosphatases. Plant Soil and Environment, 59(10): 439-445.

[22]. Lemanowicz, J., Bartkowiak, A., 2013. Diagnosis of the content of selected heavy metals in the soils of the Patuki region against their enzymatic activity. Archives of Environmental Protection, 39(3): 23-32. http://dx.doi.org/10.2478/aep-2013-0026

[23]. Lemanowicz, J., Krzyżaniak, M., 2015. Vertical distribution of phosphorus concentrations, phosphatase activity and further soil chemical properties in salt-affected Mollic Gleysols in Poland. Environmental Earth Sciences, 74(3): 2719-2728.

http://dx.doi.org/10.1007/s12665-015-4294-x

[24]. Liang, X., Liu, J., Chen, Y., Li, H., Ye, Y., Nie, Z., Su, M., Xu, Z., 2010. Effect of pH on the release of soil colloidal phosphorus. Journal of Soils and Sediments, 10(8): 1548-1556. http://dx.doi.org/10.1007/s11368-010-0275-6

[25]. Mahmood, I.A., Ali, A., Aslam, M., Shahzad, A., Sultan, T., Hussain, F., 2013. Phosphorus availability in different salt-affected soils as influenced by crop residue incorporation. International Journal of Agricultural and Biology, 15: 472-478.

[26]. Mehta, N.C., Legg, J.O., Goring, C.A., Black, C.A., 1954. Determination of organic phosphorus in soils. Soil Science Society of America Proceedings, 44: 443-449.

http://dx.doi.org/10.2136/sssaj1954.03615995001800040023x 
[27]. Ochman, D., Jezierski, P., 2011. Impact of sedimentation waters on the soils absorbing complex in the region of ,'Zelazny Most" tailings impoundment. Environmental Protection and Natural Resources, 49: 268-277.

[28]. Ochman, D., Kawałko, D., Kaszubkiewicz, J., Jezierski, P., 2011. Content of soluble cations and anions in the water extracts from the saline soils supplied with flotation water infiltrating from tailings impoundment "Żelazny Most”. Environmental Protection and Natural Resources, 48: 266-275.

[29]. Paluszek, J., 2014. Estimation of cation exchange capacity and cation saturation of Luvisols developed from loess. Journal of Elementology, 19(4): 1085-1098.

http://dx.doi.org/10.5601/jelem.2014.19.3.400

[30]. Pan, Ch., Liu, Ch., Zhao, H., Wang, Y., 2013. Changes of soil physico-chemical properties and enzyme activities in relation to grassland salinization. European Journal of Soil Biology, 55: 13-19. doi:10.1016/j.ejsobi.2012.09.009

[31]. Peinemann, N., Amiotti, N.M., Zalba, P., Villamil, M.B., 2000. Effect of clay minerals and organic matter on the cation exchange capacity of silt fractions. Journal of Plant Nutrition and Soil Science, 163: 47-52.

http://dx.doi.org/10.1002/(SICI)1522-2624(200002)163:1<47::AID-JPLN47>3.0.CO;2-A

[32]. Piernik, A., Hulisz, P., 2011. Soil-plant relations in inland natural and anthropogenic saline habitats. European Journal of Plant Science and Biotechnology, 5(2): 37-43.

[33]. PN-EN ISO 11260, 2011. Soil quality - Determination of effective cations exchange capacity and base saturation level using barium chloride solution. Polish Standards Committee, Warszawa.

[34]. PN-R-04023, 1996. Chemical and agricultural analysis - Determination of the content of available phosphorus in mineral soils. Polish Standards Committee, Warszawa.

[35]. Qadir, M., Schubert, S., 2002. Degradation processes and nutrient constraints in sodic soils. Land Degradation and Development, 13: 275-294. http://dx.doi.org/10.1002/Idr.504

[36]. Rao, D.L.N., Pathak, H., 1996. Ameliorative influence of organic matter on biological activity of salt-affected soils. Arid Soil Research and Rehabilitation, 10(4): 311-319.

http://dx.doi.org/10.1080/15324989609381446

[37]. Rengasamy, P., Olsson, K.A., 1991. Sodicity and soil structure. Australian Journal of Soil Research, 29(6): 935-952.

[38]. Ross, D.S., Matschonat, G., Skyllberg, U., 2008. Cation exchange in forest soils: The need for a new perspective. European Journal of Soil Science, 59(6): 1141-1159. http://dx.doi.org/10.1111/j.1365-2389.2008.01069.x

[39]. Ross, D.S., Bartlett, R.J., Magdoff, F.R., 1991. Exchangeable cations and the pH-independent distribution of cation exchange capacities in Spodosols of a forested watershed. In: PlantSoil Interactions at Low pH, R.J. Wright, V.C. Baligar and R.P. Murmann (eds.), Kluwer Academic Publishers, Dordrecht, the Netherlands: 81-92.

[40]. Siddikee, M.A., Tipayno, S.C., Kim, K., Chung, J., Sa, T., 2011. Influence of varying degree of salinity-sodicity stress on enzyme activities and bacterial populations of coastal soils of Yellow Sea, South Korea. Journal of Microbiology and Biotechnology, 21(4): 341-346. http://dx.doi.org/10.4014/jmb.1012.12015

[41]. Tabatabai, M.A., Bremner, J.M., 1969. Use of p-nitrophenyl phosphate for assay of soil phosphatase activity. Soil Biology and Biochemistry, 1(4): 301-307.

https://doi.org/10.1016/0038-0717(69)90012-1

[42]. Tripathi, S., Chakraborty, A., Chakrabarti, K., Bandyopadhyay, B.K., 2007. Enzyme activities and microbial biomass in coastal soils of India. Soil Biology and Biochemistry, 39(11): 2840-2848. http://dx.doi.org/101016/j.soilbio.2007.05.027

[43]. Wamelink, G.W.W., de Knegt, B., Pouwels, R., Schuiling, C., Wegman, R.M.A., Schmidt, A.M., van Dobben, H.F., Sanders, M.E., 2013. Considerable environmental bottlenecks for species listed in the Habitats and Birds Directives in the Netherlands. Biological Conservation, 165: 43-53. http://dx.doi.org/10.1016/j.biocon.2013.05.012 
[44]. Wang, J.B., Chen, Z.H., Chen, L.J., Zhu, A.N., Wu, Z.J., 2011. Surface soil phosphorus and phosphatase activities affected by tillage and crop residue input amounts. Plant, Soil and Environment, 57(6): 251-257.

[45]. Ward, J.H., 1963. Hierarchical grouping to optimize an objective function. Journal of the American Statistical Association, 58: 236-244.

[46]. Wilding, L.P., 1985. Spatial variability: Its documentation, accommodation, and implication to soil surveys. In: Soil Spatial Variability, D.R. Nielsen, J. Bouma (eds.), Pudoc, Wageningen: 166-194.

[47]. Xiao, R., Bai, J.H., Gao, H.F., Huang, L.B., Deng, W., 2012. Spatial distribution of phosphorus in marsh soils of a typical land/inland water ecotone along a hydrological gradient. CATENA 98: 96-103. doi:10.1016/j.catena.2012.06.008

[48]. Zhang, T.B., Kang, Y., Liu, S.H., Liu, S.P., 2014. Alkaline phosphatase activity and its relationship to soil properties in a saline-sodic soil reclaimed by cropping wolfberry (Lycium barbarum L.) with drip irrigation. Paddy and Water Environment, 12(2): 309-317.

http://dx.doi.org/10.1007/s10333-013-0384-0 